\title{
Karakter morfologi akar sebagai indikator kekurangan air pada padi lokal Superwin \\ (Root-morphological characters as water-deficit indicators in local rice Superwin)
}

\author{
Patricia Claudya Torey ${ }^{1)}$, Nio Song $A i^{2)^{*}}$, Parluhutan Siahaan ${ }^{2)}$, Susan M Mambu( ${ }^{2)}$ \\ 1) Alumni Jurusan Biologi Fakultas MIPA Universitas Sam Ratulangi Manado 95115 \\ 2) Jurusan Biologi Fakultas MIPA Universitas Sam Ratulangi Manado 95115 \\ *Email korespondensi: nio_ai@yahoo.com
}

Diterima 31 Juli 2013, diterima untuk dipublikasikan 7 Agustus 2013

\begin{abstract}
Abstrak
Evaluasi karakter morfologi akar telah dilakukan untuk menentukan karakter morfologi akar yang potensial sebagai indikator adanya kekurangan air pada padi (Oryza sativa L.) di antara panjang akar, volume akar, berat basah akar, berat kering akar, rasio akar:tajuk dan rasio panjang akar:tinggi tanaman. Eksperimen ini dilakukan di rumah kaca dan menggunakan 2 varietas padi (Superwin dan IR 64) pada fase vegetatif yang ditumbuhkan pada media tanah di polybag dengan perlakuan kekeringan (tidak disirami selama 14 hari) dan disirami sampai kapasitas lapang (kontrol). Panjang akar dan rasio panjang akar:tinggi tanaman dapat dijadikan indikator kekurangan air pada padi Superwin dan IR 64. Superwin yang merupakan padi sawah dapat dipertimbangkan untuk ditanam di lahan kering.

Kata kunci: indikator, kekeringan, morfologi akar
\end{abstract}

\section{Abstract}

Root-morphological characters in rice (Oryza sativa L.) were evaluated to determine the potential characters as water-deficit indicators among the length, volume, fresh weight, dry weight, ratio root:shoot and ratio root length:plant height. The experiment was conducted in the glasshouse using 2 rice varieties (cv. Superwin and IR 64) grown in the soil mixture at the vegetative phase. The treatments in this experiment were water deficit (without water for 14 days) and wellwatered (watering until field capacity). The root length and ratio root length:plant height were potential as water- deficit indicators in Superwin dan IR 64. The upland rice, Superwin, should be considered to be cultivated in the water limited area.

Keywords: drought, indicator, root morphology

\section{PENDAHULUAN}

Padi merupakan bahan
makanan pokok bagi penduduk Indonesia. Kebutuhan pangan yang berupa beras semakin meningkat seiring dengan meningkatnya jumlah penduduk Indonesia. Salah satu masalah utama yang menjadi kendala dalam proses pengembangan tanaman padi (Oryza sativa L.) di Indonesia adalah kekurangan air yang melanda areal persawahan sehingga menjadi suatu ancaman untuk produksi padi (Irawati 2009).

Kemampuan akar mengabsorbsi air dengan cara memaksimalkan sistem perakaran merupakan salah satu pendekatan 
utama yang biasanya digunakan untuk melihat kemampuan adaptasi dari tanaman terhadap kekurangan air yang terjadi (Efendi 2009). Tanaman yang memiliki volume akar yang tinggi, akan mampu mengabsorbsi air lebih banyak sehingga mampu bertahan pada kondisi kekurangan air (Palupi dan Dedywiryanto 2008). Meningkatnya panjang akar dan volume akar merupakan respon morfologi yang penting dalam proses adaptasi tanaman terhadap kekurangan air (Budiasih 2009). Penelitian kekurangan air yang diinduksi larutan PEG 6000 pada kecambah padi menunjukkan bahwa rata-rata panjang akar lebih besar pada varietas yang memiliki tingkat toleransi lebih tinggi dibandingkan varietas yang relatif tidak toleran. Pemanjangan akar tanaman dalam upaya untuk mencari air merupakan salah satu indikator padi yang toleran terhadap kekurangan air (Djazuli 2010; Aryati 2011).

Padi varietas Superwin merupakan padi jenis lokal yang banyak dibudidayakan oleh petani di Sulawesi Utara (Tamburian 2011). Superwin juga merupakan padi yang paling disukai karena varietas padi tersebut tahan terhadap terpaan angin dan gangguan hama wereng, serta berasnya putih dan rasanya enak (Setyowati dan Wardah 1999). Publikasi mengenai kajian respon padi varietas Superwin terhadap kekurangan air berdasarkan karakter morfologi akar belum ada. Berdasarkan pokok-pokok pikiran di atas, penelitian ini akan difokuskan pada beberapa karakter akar yang dapat dipakai sebagai indikator resistensi tanaman padi varietas Superwin terhadap kekurangan air, seperti panjang akar, volume akar, berat basah akar, berat kering akar, berat jenis akar, rasio akar:tajuk, serta rasio panjang akar:tinggi tanaman. Hasil penelitian ini diharapkan dapat memberikan informasi tentang potensi karakter morfologi akar padi (Oryza sativa L.) sebagai indikator terjadinya kekurangan air pada tanaman.

\section{METODE}

Penelitian ini dilaksanakan pada bulan April dan Mei 2013 selama 4 minggu di rumah kaca di kelurahan Tingkulu, Manado, Sulawesi Utara dan Laboratorium Biologi Konservasi Jurusan Biologi FMIPA Universitas Sam Ratulangi. Alat yang digunakan yaitu botol air mineral ukuran 1.500 $\mathrm{ml}$, timbangan, penggaris, gelas ukur $5 \mathrm{ml}$ dan $25 \mathrm{ml}$, dan oven. Bahan yang digunakan yaitu padi varietas Superwin, padi varietas IR 64, larutan pemutih komersial, pupuk gandasil D dan akuades. Media tanam dalam penelitian ini akan berupa campuran tanah taman, pupuk kandang dan sekam dengan perbandingan 5:1:1.

\section{Persiapan tanaman sebelum perlakuan dan desain eksperimen} Benih direndam di dalam air garam selama 2 jam kemudian disterilisasi dengan menggunakan pemutih komersial $2 \%$ selanjutnya dikecambahkan selama 3 hari. Tiga benih yang telah berkecambah ditanam pada tiap botol, selanjutnya benih disiram dengan campuran air dan pupuk (10 g pupuk Gandasil D dalam $10 \mathrm{~L}$ air) sampai pada kapasitas lapang. Tanaman terus disiram sampai kapasitas lapang tiap 2 hari sampai mencapai tahap 2 daun yang berkembang penuh (2 fully expanded leaf), dan perlakuan cekaman kekeringan diberikan saat tanaman berumur 14 hari setelah tanam dengan menggunakan hanya 1 tanaman pada tiap botol. Eksperimen ini merupakan percobaan faktorial 
dalam Rancangan Acak Lengkap yang terdiri dari 2 varietas padi, 2 perlakuan pengairan dengan 5 kali ulangan. Perlakuan pengairan yang dilakukan adalah diairi sampai 100\% kapasitas lapang atau kontrol (DA) dan tidak diairi selama 14 hari (TA). Tanaman DA hanya disiram dengan air tanpa menggunakan pupuk, sedangkan tanaman TA tidak disirami sama sekali (Nio dan Ludong 2011).Pengambilan sampel tanaman untuk pengamatan parameter pada hari ke-14.

\section{Pengambilan data}

Enam parameter yang diamati dalam penelitian ini yaitu panjang akar (Rusd 2009), volume akar (Munarso 2011), berat basah akar (Syaputra 2011), berat kering akar, rasio akar:tajuk (Sinaga 2008), rasio panjang akar:tinggi tanaman (Suprihatno dan Suardi 2007). Volume akar dilakukan dengan menentukan volume awal air yang akan dimasukkan ke dalam gelas ukur, memasukkannya ke dalam gelas ukur dan kemudian mencatat pertambahan volume air setelah memasukkan akar ke dalamnya, lalu menghitung selisih volume air saat akar dimasukkan ke dalamnya dengan volume awal air (Munarso, 2011). Rasio akar:tajuk diperoleh dengan cara membandingkan berat kering akar dan

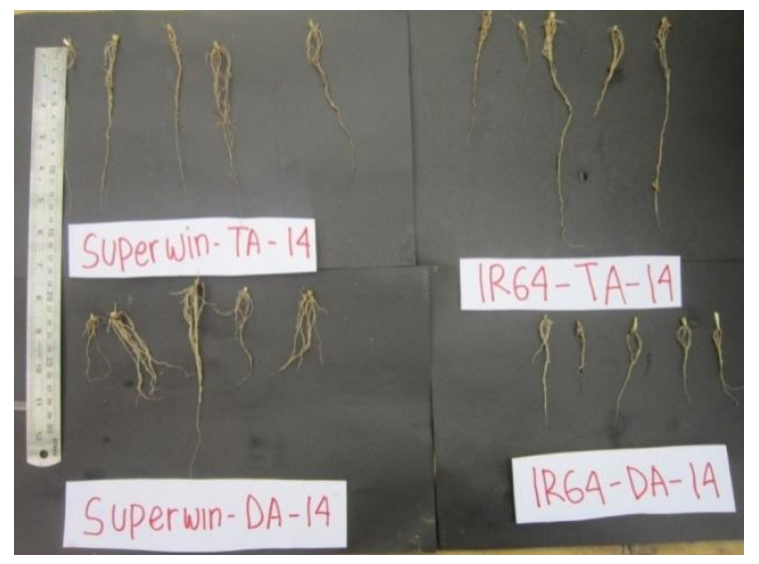

berat kering tajuk. Untuk menggambarkan penggunaan air oleh tanaman, transpirasi kumulatif ditentukan menurut Nio dan Ludong (2011) dan kandungan air tanah ditentukan menurut Rasyid et al. (2010).

\section{Analisis data}

Data yang diperoleh akan dianalisis dengan analisis sidik ragam dalam rancangan acak lengkap faktorial yang dilanjutkan dengan uji BNT 5\% untuk menunjukkan ada tidaknya perbedaan yang signifikan (Sastrosupadi 2000).

\section{HASIL DAN PEMBAHASAN}

Pada saat kekurangan air, kemampuan tanaman untuk mempertahankan pertumbuhan akar sangat penting untuk penyerapan air dan unsur-unsur hara (Hamin et al. 1996 dalam Afa 2013). Adanya pemanjangan akar ke lapisan tanah yang lebih dalam pada saat terjadi kekurangan air, menunjukkan bahwa tanaman tersebut resisten dan dapat dijadikan karakter morfologi akar yang potensial (Nio dan Torey 2013). Hasil penelitian ini menunjukkan bahwa pada hari ke-14 panjang akar padi Superwin dan IR 64 pada perlakuan yang tidak diairi $67 \%$ lebih besar daripada yang diairi (Gambar 1 dan Tabel 1), sehingga dapat dikatakan

Gambar 1. Penampilan padi Superwin dan IR 64 yang menunjukkan panjang akar pada perlakuan (DA) dan tidak diairi (TA) pada hari ke-14 
bahwa panjang akar merupakan salah satu indikator kekurangan air pada padi. Varietas Superwin yang merupakan padi sawah dan tidak diairi, memiliki panjang akar yang hampir sama dengan padi IR 64 yang merupakan padi ladang dan tidak diairi, sehingga dapat dikatakan bahwa padi varietas Superwin potensial untuk ditanam di lahan yang kekurangan air.

Volume akar dipengaruhi oleh perbedaan genotipe dan sistem pengairan (Munarso 2011). Volume akar padi varietas Superwin dan IR 64 dengan 2 macam perlakuan yaitu diairi dan tidak diairi pada hari ke-14 dapat dilihat pada Tabel 1. Varietas Superwin pada hari ke-0 memiliki volume akar yaitu $0,1 \mathrm{~cm}^{3}$ dan untuk IR 64 yaitu $0,12 \mathrm{~cm}^{3}$. Hasil analisis sidik ragam menunjukkan bahwa faktor varietas, perlakuan dan interaksi antara faktor varietas dan perlakuan tidak menyebabkan perbedaan volume akar yang nyata pada hari ke-14. Hal ini dapat disebabkan karena volume akar tanaman padi yang berumur 30 hari setelah tanam masih terlalu kecil dan periode perlakuan tidak diairi selama 14 hari masih terlalu singkat. Dengan demikian volume akar tidak dapat dipakai sebagai indikator kekurangan air pada padi Superwin.

Berat basah akar digunakan untuk mengetahui kemampuan tanaman dalam menyerap air. Untuk mengetahui biomassa total akar di dalam tanah maka pengamatan berat basah akar merupakan variable pengamatan yang sesuai. Kebutuhan tanaman akan air dapat dipenuhi dengan jalan penyerapan oleh akar. Kadar air di dalam tanah dan kemampuan akar untuk menyerap air sangat mempengaruhi besarnya air yang diserap oleh akar sehingga kemampuan akar dalam menyerap air tersebut sangat mempengaruhi berat basah akar (Jadid 2007). Berat basah akar pada varietas Superwin dan IR 64 tidak berbeda nyata antara perlakuan diairi dan tidak diairi (Tabel 1), sehingga dapat dikatakan bahwa berat basah akar tidak dapat dijadikan indikator kekurangan air pada tanaman.

Berat kering akar mengindikasikan kemampuan suatu tanaman untuk menyerap air, karena tanaman yang memiliki berat kering akar yang tinggi memiliki perakaran yang lebih besar serta memiliki tingkat toleransi yang lebih tinggi terhadap kekeringan dibandingkan dengan tanaman dengan berat kering akar yang rendah (Kurniasih dan Wulandhany 2009). Hasil yang sama diamati pada IR 64 dalam penelitian ini, yaitu berat kering akar pada perlakuan tidak diairi lebih besar daripada yang tidak diairi, tetapi tidak demikian halnya pada Superwin. Berat kering akar IR64 pada perlakuan diairi adalah terkecil dan lebih kecil daripada berat kering akar Superwin dan IR 64 yang tidak diairi, tetapi tidak berbeda nyata dengan berat kering akar Superwin yang diairi. Oleh sebab itu berat kering akar merupakan indikator kekurangan air yang potensial pada IR 64, tetapi bukan merupakan indikator pada Superwin.

Dalam kondisi kekurangan air, distribusi asimilat dalam tubuh tanaman yang diperoleh dari sumber sebagian besarnya akan didistribusikan ke akar, agar akar dapat tumbuh dan dapat memenuhi kebutuhan tanaman akan air (Kurniasih dan Wulandhany 2009). Tanaman yang memiliki rasio panjang akar dan tinggi tanaman yang lebih besar pada saat kekurangan air menunjukkan bahwa tanaman tersebut resisten (Nio dan Torey 2013). Rasio akar:tajuk padi varietas 
Torey dkk., Karakter morfologi .... 61

Superwin dan IR 64 yang diairi dan tidak diairi selama 14 hari tidak berbeda nyata (Tabel 1). Rasio akar:tajuk pada penelitian ini tidak berbeda nyata dan tidak dapat dijadikan sebagai indikator kekurangan air pada padi Superwin dan IR 64. Hal ini disebabkan karena lama perlakuan yang hanya dalam waktu 2 minggu sehingga hanya mencapai tahap vegetatif.

Pada hari ke-14 rasio panjang akar:tinggi tanaman padi Superwin dan IR 64 pada perlakuan yang tidak diairi $47 \%$ lebih besar daripada yang diairi. Pada kondisi kekurangan air, sebagian besar asimilat dalam tubuh tanaman yang diperoleh dari sumber akan didistribusikan ke akar, agar akar dapat tumbuh dan dapat memenuhi kebutuhan tanaman akan air (Kurniasih dan Wulandhany, 2009). Penelitian tanaman padi genotipe B1485A/BP5 dengan perlakuan kekurangan air yang diinduksi dengan PEG 6000 menunjukkan adanya pemanjangan akar dan terhambatnya pertumbuhan tajuk, sehingga genotipe ini memiliki nilai rasio panjang akar:tinggi tanaman yang lebih besar. Rasio panjang akar:tinggi tanaman pada padi tahan kering lebih besar daripada yang tidak tahan kering (Suprihatno dan Suardi, 2007). Tanaman yang memiliki rasio panjang akar:tinggi tanaman yang lebih besar pada saat kekurangan air menunjukkan bahwa tanaman tersebut resisten terhadap kekurangan air dan merupakan karakter morfologi akar yang potensial sebagai indikator adanya kekurangan air pada tanaman (Nio dan Torey, 2013). Padi varietas Superwin yang merupakan padi sawah memiliki nilai rasio panjang akar:tinggi tanaman yang tidak berbeda nyata dengan varietas IR 64 yang merupakan padi ladang, sehingga dapat dikatakan bahwa padi varietas Superwin potensial untuk ditanam di lahan kering berdasarkan karakter tersebut.

Ada dua proses kehilangan air pada tanaman yaitu evaporasi dan transpirasi. Proses kehilangan air yang disebabkan penguapan oleh permukaan tanah dan badan air disebut evaporasi, sedangkan kehilangan air yang disebabkan oleh penguapan melalui bagian dalam tubuh tanaman disebut evapotranspirasi. Kedua proses tersebut biasanya disebut evapotranspirasi (Purba 2011). Hasil penelitian ini menunjukkan bahwa pada awal perlakuan transpirasi kumulatif pada kedua varietas ini hampir sama, namun pada akhir perlakuan transpirasi kumultaif pada perlakuan diairi lebih besar daripada yang tidak diairi. Laju transpirasi pada tanaman yang tidak diairi lebih kecil akibat menutupnya stomata (Lestari 2006). Besarnya jumlah transpirasi pada kedua varietas ini terlihat berbeda karena untuk varietas Superwin pada perlakuan tidak diairi pada hari terakhirnya memiliki nilai akhir yang lebih kecil yaitu $25,77 \mathrm{~mm}^{3}$ dibanding IR 64 yaitu 30,30 $\mathrm{mm}^{3}$. Kandungan air tanah pada varietas Superwin perlakuan diairi pada hari ke-0 memiliki nilai $59,85 \%$ dan varietas IR 64 perlakuan diairi yaitu $62,83 \%$. Varietas Superwin pada perlakuan diairi memiliki nilai 60,35 pada perlakuan tidak diairi yaitu 54,29 , sedangkan untuk varietas IR 64 pada perlakuan diairi yaitu 48,10 dan untuk yang tidak diairi adalah 42,936. Kandungan air tanah pada varietas Superwin perlakuan tidak diari pada pada hari ke-14 menunjukkan penurunan kandungan air tanah sebanyak $20 \%$ dan pada varietas IR 64 perlakuan tidak diairi pada hari ke14 menunjukkan adanya penurunan kandungan air tanah sebanyak $22 \%$. 
Di antara 6 karakter morfologi akar yang diamati, yaitu panjang akar, volume akar, berat basah akar, berat kering akar, rasio akar:tajuk serta rasio panjang akar:tinggi tanaman, panjang akar dan rasio panjang akar:tinggi tanaman potensial sebagai indikator kekurangan air pada padi Superwin dan IR 64. Pada saat tidak diairi, akar tumbuh lebih panjang dan rasio panjang akar:tinggi tanaman lebih besar daripada saat diairi.

Padi yang memiliki kemampuan untuk bertahan pada kondisi kekurangan air memiliki perakaran yang besar dan panjang, sehingga dengan sistem perakaran tersebut, tanaman padi dapat menembus lapisan tanah yang lebih dalam untuk menjaga status air pada jaringan tanaman (Suprianto, 1998). Hasil pengamatan pada panjang akar dan rasio panjang akar:tinggi tanaman pada padi varietas Superwin menunjukkan respon yang sama dengan varietas IR 64 pada saat tidak diairi jika dibandingkan dengan saat diairi. Oleh sebab itu varietas Superwin yang merupakan padi sawah potensial untuk ditanam di lahan kering. Penelitian lanjutan yang mengevaluasi respon varietas Superwin terhadap kekurangan air pada fase generatif perlu dilakukan untuk memperkuat kesimpulan tersebut.

\section{KESIMPULAN}

Panjang akar dan rasio panjang akar:tinggi tanaman dapat dijadikan indikator kekurangan air pada padi Superwin dan IR 64. Pada saat tidak diairi akar tumbuh lebih panjang dan rasio panjang akar: tinggi tanaman lebih besar daripada saat diairi. Superwin yang merupakan padi sawah memiliki respons terhadap kekurangan air seperti varietas IR 64 yang merupakan padi ladang,
Superwin dapat dipertimbangkan untuk ditanam di lahan kering.

\section{DAFTAR PUSTAKA}

Afa LA (2013) Seleksi padi hibrida terhadap kekeringan untuk pengembangan di lahan sawah tadah hujan. Skripsi. IPB. Bogor

Aryati V (2011) Metode pengusangan cepat terkontrol untuk mengidentifikasi secara dini genotipe padi gogo (Oryza sativa L.) toleran kekeringan. Tesis. IPB. Bogor

Budiasih (2009) Respon tanaman padi gogo terhadap cekaman kekeringan. Ganec Swara Edisi Khusus 3:22-27

Djazuli M (2010) Pengaruh cekaman kekeringan terhadap pertumbuhan dan beberapa karakter morfo-fisiologis tanaman nilam. Bul Littro 21: 8-17

Efendi R (2009) Metode dan karakter seleksi toleransi genotipe jagung terhadap cekaman kekeringan. Tesis. FMIPA. Bogor

Irawati N (2009) Analisis sikap dan kepuasan petani padi terhadap benih padi (Oryza sativa) varietas unggul di Kota Solok, Sumatera Barat. Skripsi. Fakultas Ekonomi dan Manajemen. IPB. Bogor

Jadid MN (2007) Uji toleransi aksesi kapas (Gossypium hirsutum L.) terhadap cekaman kekeringan dengan menggunakan polietilena glikol (PEG) 6000. Skripsi. Fakultas Sains dan Teknologi Universitas Islam Negeri Malang. Malang

Kurniasih B, Wulandhany F (2009) Penggulungan daun, pertumbuhan tajuk dan akar 
beberapa varietas padi gogo pada kondisi cekaman air yang berbeda. Agrivita 31:118-128

Lestari EG (2006) Hubungan antara kerapatan stomata dengan ketahanan kekeringan pada somaklon padi Gajahmungkur, Towuti, dan IR 64. Biodiversitas 7:44-48

Munarso PY (2011) Keragaan padi hibrida pada sistem pengairan intermittent dan tergenang. Penelitian Pertanian Tanaman Pangan 30:189-195

Nio SA, Ludong DPM (2011) Evaluasi indikator toleransi terhadap cekaman kekeringan pada varietas padi yang dibudidayakan di Sulawesi Utara. Laporan Penelitian Fundamental. Fakultas MIPA UNSRAT. Manado

Nio SA, Torey P (2013) Karakter morfologi akar sebagai indikator kekurangan air pada tanaman. J Bios Logos 3:31-39

Palupi ER, Dedywiryanto Y (2008) Kajian karakter toleransi cekaman kekeringan pada empat genotipe bibit kelapa sawit (Elaeis guineensis Jacq). Bul Agron 36:24-32

Purba JH (2011) Kebutuhan dan cara pemberian air irigasi untuk tanaman padi sawah (Oryza sativa L.). Widyatech J Sains dan Teknologi 10:145-155

Rasyid B, Solo SRS, Sutomo F (2010) Respon tanaman jagung (Zea mays) pada berbagai regim air tanah dan pemberian pupuk nitrogen. Prosiding Pekan Serealia Nasional.

Rusd MIA (2011) Pengujian toleransi padi (Oryza sativa L.) terhadap salinitas pada fase perkecambahan. Skripsi. IPB. Bogor

Sastrosupadi A (2000) Rancangan percobaan praktis bidang pertanian. Kanisius. Yogyakarta

Setyowati FM, Wardah (1999) Pemanfaatan berbagai jenis tumbuhan pada beberapa etnis di sekitar kawasan T.N. Bogani Nani Wartabone dan Cagar Alam Gunung Ambang. Balitbang Botani, Puslitbang Biologi - LIPI

Sinaga R (2008) Keterkaitan nisbah tajuk akar dan efisiensi penggunaan air pada rumput gajah dan rumput raja akibat penurunan ketersediaan air tanah. Jurnal Biologi Sumatera 3: 29-35

Suprianto E (1998) Evaluasi beberapa varietas dan galur padi pada kondisi kekeringan. Skripsi. IPB. Bogor

Suprihatno B, Suardi D (2007) Kemampuan tembus akar galur-galur padi sawah generasi menengah. Apresiasi hasil penelitian padi. www.litbang.deptan.go.id/speci al/padi/bbpadi_2008_p2bn2_0 5.pdf. Diakses pada 28 September 2012

Syaputra T (2011) Pembuatan dan pengujian wadah semai berbahan dasar organik untuk pembibitan gmelina (Gmelina arborea Roxb.) Tesis. IPB. Bogor.

Tamburian Y (2011) Pengkajian peningkatan produktivitas padi sawah melalui penerapan PTT di Kabupaten Bolmong Sulawesi Utara. BPTP Sulawesi Utara 
64 JURNAL BIOS LOGOS, AGUSTUS 2013, VOL. 3 NOMOR 2

Tabel 1. Panjang akar, volume akar, berat basah akar, berat kering akar, rasio akar:tajuk, dan rasio panjang akar:tinggi tanaman padi varietas Superwin d an IR64 yang diairi sampai 100\% kapasitas lapang (DA) dan tidak diairi (TA) pada hari ke14 (rata-rata \pm standar error)

\begin{tabular}{|c|c|c|c|c|c|c|c|}
\hline Varietas & Perlakuan & $\begin{array}{c}\text { Panjang akar } \\
\text { (cm) }\end{array}$ & $\begin{array}{l}\text { Volume akar } \\
\left(\mathrm{cm}^{3}\right)\end{array}$ & $\begin{array}{l}\text { Berat basah } \\
\text { akar (g) }\end{array}$ & $\begin{array}{l}\text { Berat kering akar } \\
\text { (g) }\end{array}$ & Rasio akar: tajuk & $\begin{array}{l}\text { Rasio panjang } \\
\text { akar : tinggi } \\
\text { tanaman }\end{array}$ \\
\hline \multirow{2}{*}{ Superwin } & DA & $10,6 \pm 1,3729^{a}$ & $0,28 \pm 0,0583^{\operatorname{tn}}$ & $0,0831 \pm 0,025^{\operatorname{tn}}$ & $0,0109 \pm 0,0026^{\mathrm{ab}}$ & $0,1813 \pm 0,0583^{\operatorname{tn}}$ & $0,2974 \pm 0,0331^{\mathrm{ab}}$ \\
\hline & TA & $15,44 \pm 0,5055^{b}$ & $0,18 \pm 0,02^{\operatorname{tn}}$ & $0,0428 \pm 0,0056^{\text {tn }}$ & $0,0138 \pm 0,0018^{b}$ & $0,1276 \pm 0,0058^{\text {tn }}$ & $0,4420 \pm 0,0157^{\mathrm{C}}$ \\
\hline \multirow{2}{*}{ IR64 } & $\mathrm{DA}$ & $7,4 \pm 0,5797^{a}$ & $0,18 \pm 0,02^{\text {tn }}$ & $0,0419 \pm 0,0034^{\text {tn }}$ & $0,0055 \pm 0,006^{\mathrm{a}}$ & $0,1272 \pm 0,0184^{\text {tn }}$ & $0,2920 \pm 0,0193^{\mathrm{a}}$ \\
\hline & TA & $14,66 \pm 2,4929^{b}$ & $0,2 \pm 0,0316^{\text {tn }}$ & $0,0506 \pm 0.0111^{\text {tn }}$ & $0,0129 \pm 0,0025^{b}$ & $0,1120 \pm 0,0118^{\mathrm{tn}}$ & $0,4239 \pm 0,0570^{b}$ \\
\hline
\end{tabular}

Keterangan: Angka yang diikuti oleh huruf yang berbeda pada kolom yang sama adalah berbeda nyata berdasarkan uji BNT pada taraf signifikansi $5 \%$, tn : tidak berbeda nyata 